\title{
ARE FISCAL ADJUSTMENTS LESS SUCCESSFUL IN DECENTRALIZED GOVERNMENTS?
}

\author{
CHRISTOPH A. SCHALTEGGER \\ LARS P. FELD \\ CESIFO WORKING PAPER NO. 1946 \\ CATEGORY 1: Public FinANCE \\ MARCH 2007
}

An electronic version of the paper may be downloaded

- from the SSRN website:

- from the RePEc website:

www.SSRN.com

www.RePEc.org

- from the CESifo website: www.CESifo-group.de 


\title{
ARE FISCAL ADJUSTMENTS LESS SUCCESSFUL IN DECENTRALIZED GOVERNMENTS?
}

\begin{abstract}
A common political claim is that decentralized governments undermine policy makers' ability to fight fiscal imbalance. This paper examines how different fiscal institutions influence the likelihood of a successful fiscal adjustment. Using a panel of the Swiss cantons from 1981 to 2001, we first analyze the episodes of tight fiscal policy and their macroeconomic consequences. Then, we empirically investigate the determinants of successful long-lasting deficit reductions. Contrary to the popular claim, we find that fiscal decentralization increases the probability of a successful fiscal consolidation. In addition, the results point to an important role of intergovernmental grants and the circumstances, in particular the size of fiscal imbalance in the years before the consolidation in determining a successful adjustment policy. Furthermore, coalition governments and large parliaments less likely implement successful fiscal stabilizations. Finally, there is some weak evidence that spending cuts are more promising in reaching a long-lasting fiscal adjustment than revenue increases.
\end{abstract}

JEL Code: E61, E63, H61.

Keywords: fiscal adjustment, consolidation policy, fiscal decentralization, fiscal institutions.

Christoph A. Schaltegger

Swiss Federal Department of Finance

Bundesgasse 3

3003 Bern

Switzerland

Christoph.Schaltegger@gs-efd.admin.ch
Lars P. Feld

University of Heidelberg

Alfred-Weber-Institute

Grabengasse 14

69117 Heidelberg

Germany

lars.feld@awi.uni-heidelberg.de

We would like to thank Charles B. Blankart, Bruno S. Frey, Friedrich Heinemann, Andreas Kyriacou, Simon Lüchinger, Alois Stutzer, Kurt Stalder and Viktor Steiner for very valuable comments and suggestions. Lars P. Feld acknowledges a grant from the German Science Foundation (DFG SPP 1142). 


\section{Introduction}

The possibility that fiscal policy decisions in a democracy are biased towards deficit finance and excessive spending with targeted benefits and diverse costs has been recognized at least since the studies by Buchanan and Wagner (1977) or Weingast, Shepsle and Johnson (1981). ${ }^{1}$ In order to tackle problems of mounting public deficits created by an "unsustainable" fiscal policy in the 1970s and 1980s many governments have implemented statutory limitations to balance their budgets (Poterba, 1997). As has been shown by different authors, such balanced-budget requirements may be an effective instrument in reducing fiscal imbalance if adequately designed (Shadbegian, 1999; Poterba, 1996; Bohn and Inman, 1996, Bayoumi and Eichengreen, 1995). ${ }^{2}$

In order to comply with these balanced budget rules, many governments have started implementing fiscal consolidation policies. Substantial research efforts have been focused on the macroeconomic effects to these fiscal adjustments as well as on identifying those determinants that favor long-lasting and sustainable consolidations. ${ }^{3}$ In a pioneering work, Giavazzi and Pagano (1990) study two major fiscal contractions in Denmark (1983-1986) and in Ireland (1987-1989) that were associated with surprising, immediate non-Keynesian expansionary economic effects. The explanation brought up by the two authors (Giavazzi and Pagano, 1996) as well as by Bertola and Drazen (1993) is that the wealth effect by a credibly announced long-lasting spending cut leads to higher consumption today and offsets the Keynesian recessive impact of reduced

1 More recently, Alesina and Perotti (1995) discuss different politico-institutional explanations why some governments accumulated large and persistent debt while others did not.

2 However, von Hagen (1991) presents evidence that balanced budget rules on the US state level mainly shifted government debt from full faith and credit to other debt that is not fully backed by the state but did not have a significant effect on the overall level of indebtedness.

3 In the literature on the political economy of reform some authors argue that the severity of a crisis is an important aspect in successfully implementing reform policies (Krueger, 1993 or Williamson, 1994). However, as Rodrik (1996) states, the argument, that a crisis causes reform, is not free of tautology. Reform is only a political issue when actual policies are perceived not to be working. Thus, the emphasis on crisis may not be a good explanation as to what form of adjustment will be taken. 
public spending (the expectation view). According to that argument, the size of the fiscal contraction is decisive for causing expansionary effects as it signals a credible policy change, whereas only small adjustments fail to persuade consumers to anticipate their consumption to a higher income level. In fact, Sutherland (1997) and Zaghini (2001) provide evidence that sizeable adjustment policies are changing expectations on future tax liabilities and consequently boost aggregate demand immediately, especially in periods of fiscal stress, where a consolidation of the unsustainable path of fiscal policy is to be expected sooner or later. ${ }^{4}$

In an extension to the literature Alesina and Perotti (1997) and Alesina and Ardagna (1998) provide an explanation for a successful fiscal stabilization due to labor market effects affecting the cost of firms (the labor market view or composition view). They show that expansionary fiscal consolidation is more likely and sustainable if relying primarily on spending cuts. Even in the case where the adjustment is of the same size in terms of reducing the primary budget deficit, cutting back spending induces a more promising consolidation than tax increases. In addition, they argue that the composition of spending cuts matters. Particularly successful deficit-to-GDP and debt-to-GDP reductions are associated with cuts on government transfers, welfare spending and government wages. However, if the budget consolidation relies on reductions of public investment, the adjustments tend to be unsuccessful.

Recently, Ardagna (2004) evaluated the relative importance of the two basic views of nonKeynesian effects of consolidation. She provides evidence that the composition of stabilization policy matters for economic growth mainly via the labor market effect induced by moderate wage agreements. The size of the fiscal contraction is key when it comes to fight rising debt.

\footnotetext{
4 Perotti (1999) reports empirical evidence that deficit cuts are particularly expansionary when public debt is high.
} 
Ardagna's empirical findings indicate that, when governments engage in sizeable fiscal adjustments, the probability of success in the sense of a long-lasting debt reduction almost doubles.

While much research effort has subsequently been devoted to the question of which policy measure is particularly apt to support a successful fiscal consolidation and to the macroeconomic consequences of fiscal adjustments, the politico-institutional aspect of fiscal adjustments is much less elaborated. Does the institutional framework in which the fiscal stabilization has to be approved play a decisive role? A common claim by political leaders is, that austere fiscal adjustments are difficult to achieve in a decentralized government even if seen as necessary by most interest groups since too many veto-players can delay policy decisions. We argue that fiscal decentralization does not necessarily delay successful fiscal adjustments since it fosters fiscal discipline and the accountability of incumbents' spending and revenue decisions. In contrast, our empirical results indicate that a decentralized government may be more successful in implementing fiscal stabilization than a centralized government.

The remainder of the paper is as follows. First we review the literature on the impact of fiscal institutions on fiscal adjustments. Then, we concentrate on episodes of fiscal adjustments in Switzerland and present some macroeconomic effects of fiscal adjustments while section five is concerned with the empirical analysis of the determinants of successful fiscal adjustments. Finally, section six concludes.

\section{Fiscal adjustments and fiscal institutions}

Several authors have analyzed the political economy of fiscal adjustments, but mostly without referring to particular institutional frameworks. Alesina and Drazen (1991), for example, developed a "war-of-attrition" model of delayed stabilizations as a result of too many parties in government that render it difficult to reach a consensus on concrete adjustment policies. In a society 
in which resources are unevenly distributed, the delay before stabilization will take place increases because interest groups believe that the burden of the adjustment policy will be onesided. The more groups are represented in government, the more probable is opposition to a consolidation process. In fact, Spolaore (1993) and Tavares (2004) present empirical evidence that broad-based coalition governments have more difficulties in committing to a stabilization program than majority governments. Mierau, Jon-A-Pin and de Haan (2005) report results that a higher number of political parties in coalition governments reduce the likelihood that a gradual adjustment process occurs.

Another political economy aspect is analyzed by Alesina, Perotti and Tavares (1998): a change in government and the popularity of the government. In their empirical study, re-election prospects of governments that follow a tight fiscal policy are evaluated. According to their findings, governments are not more frequently replaced after deficit cuts during a phase of fiscal stabilization. That means that loose fiscal discipline does not necessarily contribute to government survival. Since politicians are concerned about the popularity of their policies, the authors further examine the effect of deficit changes on the change of government's popularity. Again, the results indicate that government popularity is not systematically affected by tight adjustment policies. The findings by Mierau, Jon-A-Pin and de Haan (2005) that the chance for rapid fiscal adjustment is negatively influenced by upcoming elections do however not support this hypothesis.

A third source of political economy influence on the likelihood of fiscal adjustments comes from partisan models. Mierau, Jon-A-Pin and de Haan (2005) report empirical evidence that fiscal adjustments occur more likely under right-wing than under left-wing governments. Tavares (2004) also presents evidence that party ideologies play a role in fiscal adjustments. Governments can signal commitment to a consolidation policy by choosing those stabilization instru- 
ments that are not favored by the own constituency. That is, persistent fiscal adjustments introduced by left-wing cabinets are achieved by spending cuts. Right-wing cabinets, on the other hand, have to realize tax revenue increases for signaling credibility in their adjustment policy.

In none of these studies, institutional particularities play a role. In the respective models, governments consolidate public finances by uniform decision-making. Divided government, which may be achieved by any form of horizontal or vertical checks and balances, is not explicitly analyzed. An important institutional feature of a divided government is federalism or, more exactly, the degree of fiscal decentralization between the different layers of government. Though there is a lot of evidence that fiscal decentralization matters for the size of government (for a survey see Feld, Kirchgässner and Schaltegger, 2004), for economic performance (Thiessen, 2003), or for fiscal discipline (Rodden, 2002), there is no empirical evidence on the effect of decentralization on the persistence of fiscal adjustments up to now. Does a country's structure of the state also have an influence on the probability of successful fiscal consolidation?

In the political science literature, this question is discussed under the catchword "decisiveness" of a political system (Cox and McCubbins, 2001). ${ }^{5}$ A common political claim is that fiscal decentralization reduces the ability of political leaders to implement austere fiscal adjustments. It is argued that more policy discretion enables governments to undertake those political reforms that are strongly needed, but are not very popular. One argument why consolidations may be delayed under fiscal decentralization points to the number of veto players in the political system. According to Tsebelis (1995) or Tsebelis and Chang (2001), veto players are individuals or institutions whose agreement is necessary to change the status quo. Arguably the likelihood of a successful fiscal adjustment decreases with the number of veto players. 
Transferred to our case of fiscal federalism, the argument is that decentralized decision-making procedures increase the number of veto-players - policy-makers whose agreement for a policy change is necessary. Three different ways of obstructing fiscal consolidation in a federation are particularly important. First, many federations adopt a two-chamber system of parliament in which one chamber represents the states, cantons, provinces, Laender or regions. If the consent of the second chamber of government is necessary for fiscal consolidation, a veto position of the sub-federal jurisdictions is formally established and the fiscal consolidation becomes more difficult in a federation. The concrete institutional arrangement of the two-chamber legislature plays an important role however. In the German case, for example, the second chamber is not directly elected, but is comprised of the prime ministers of the different Laender. In this case, the support of the Laender governments is needed for fiscal consolidation. This support does not only depend on the interest of each Land, but also on partisan considerations and whether the federal government is from the same party or has the same ideological orientation. In the U.S. (and the Swiss) case, the senators are directly elected in their respective states and have incentives to minimize the contribution of their state in a fiscal consolidation process. They are however less concerned by partisan considerations, have no interest in the situation of the respective state governments and are also interested in the fiscal position of the federal level.

Second, even without considering the representation of states at the federal level, the states can counteract fiscal consolidation procedures whenever there is an established fiscal relationship between the federal and the state level. For example, the state and the federal revenue share of revenue from joint taxation systems may be an important parameter of interest in consolidation procedures. The federal level often finances particular spending programs at the state level and

5 Cox and McCubbins (2001) define decisiveness of a political system as "the ability of a state to enact and implement policy change." 
so on. In these cases, a comprehensive consolidation effort that touches upon these fiscal relationships between the center and the states needs support by the states. Third, even if the federal government is not restricted by the explicit requirement of consent with a majority of states, an autonomous federal fiscal consolidation can be counteracted by the states. After a successful fiscal consolidation, the federal government has the ability to provide additional support to the states for example in a fiscal equalization system. If the federal government consolidates, the states have an incentive to spend additionally and incur additional debt in order to be bailed-out by the federal government in the future (Goodspeed 2002, Feld and Goodspeed 2005). The following state over-spending reduces the effectiveness of federal fiscal consolidations. The incentives for over-spending are the stronger, the higher the fiscal transfers between jurisdictions are.

Thus, with increasing decentralization and fragmentation of political competencies in a country, the feasibility of a fiscal stabilization reform runs off since it becomes ever harder to find a consensus on the reform measures. Moreover, various institutional arrangements between the upperlevel and the lower-level governments and between the jurisdictions on the same level of government create political inter-dependencies. Scharpf et al. (1976) and Scharpf (1994), on the basis of the German example, claim that decentralization causes deadlocks in the political system from several complexities between different political entities that evolve over time. Such interdependencies between governments may be an important reason for delayed stabilization efforts.

In fact, some case studies have argued that government decentralization may even be dangerous when fiscal consolidation is needed. Good politics is viewed to require "strong" and "autonomous" leadership (Siebert (2005) for the case of Germany; Pinera (1994) for the case of Chile; Rentsch et al. (2004) for the case of Switzerland). In other words, this approach counts on courageous political leaders implementing austere budget policies. In search of such "heroes of the 
economics profession", one has to strengthen leadership and consequently empower political leaders with those policy instruments that are required to implement adequate reforms. Regarding New Zealand, Wallis (1999) reports how a "conspiratorial" network works towards coherent policy leadership characterized by its commitment to advance a consistent set of policy principles. An illustrative quote is a dictum by the former prime minister of Portugal, Mario Soares, who declared: "This government will be austere, uncompromising, and unpopular if that is what is required to achieve economic recovery" (Rodrik 1996, p. 9.). However, as Rodrik (1996) puts it, it is puzzling to believe that reforms aiming to make people better off should be shielded from the people's influence. If reforms are beneficial for the people as a whole, it will be possible to compensate powerful interest groups, which are hurt by the reform policy. According to Fernandez and Rodrik (1991), an explanation why governments fail to adopt reform policies is because of difficulties in identifying some of the individual gainers and losers from the reform beforehand.

On the other hand, decentralization may foster fiscal discipline if the fiscal responsibilities for each government level in a federation are clearly and transparently assigned, as Rodden (2002) and many other authors argue. The resulting fiscal competition accompanied by an absence of bail-out provisions will force governments to follow sound fiscal policies. Also, time inconsistency is a minor problem in a system with well established checks and balances: the credibility and accountability, that ex ante announced reform policies will not be quickly revised ex post, is much higher in a stable institutional framework (Pitlik, 2004). It is hard to believe that decentralization should delay or even prevent successful fiscal adjustments then. Fiscal decentralization may work as a commitment device to ensure that mutually agreed stabilization policies will eventually stay enacted over quite some time. Contrary, centralist decisions-making institutions that enable political leaders with policy discretion cannot credibly guarantee the sustainability of 
stabilization reforms for more than a gubernatorial term. According to Crepaz (1996) or Stiglitz (1998) mutually accepted agreements on fiscal adjustments are more likely to be successful since the process by which the decision has been made is seen to be fair so that even "losers" of the fiscal stabilization policy feel committed to the reform.

\section{Episodes of fiscal adjustments in Switzerland: definitions, sample and basic statistics}

We now have a closer look at the episodes of fiscal adjustment in Switzerland. Our sample covers all Swiss cantons between 1981 and 2001. Fiscal data are from the Swiss Federal Finance Department for all cantons. As we are interested in discretionary changes of cantonal fiscal policy decisions, we need to distinguish budget deficits from interest payments that cannot be considered as exogenous policy actions undertaken by the government. Thus, we remove the component of the government balance that purely results from business cycles.

Figure 1 shows the development of public debts in Swiss cantons from 1981 to 2001.

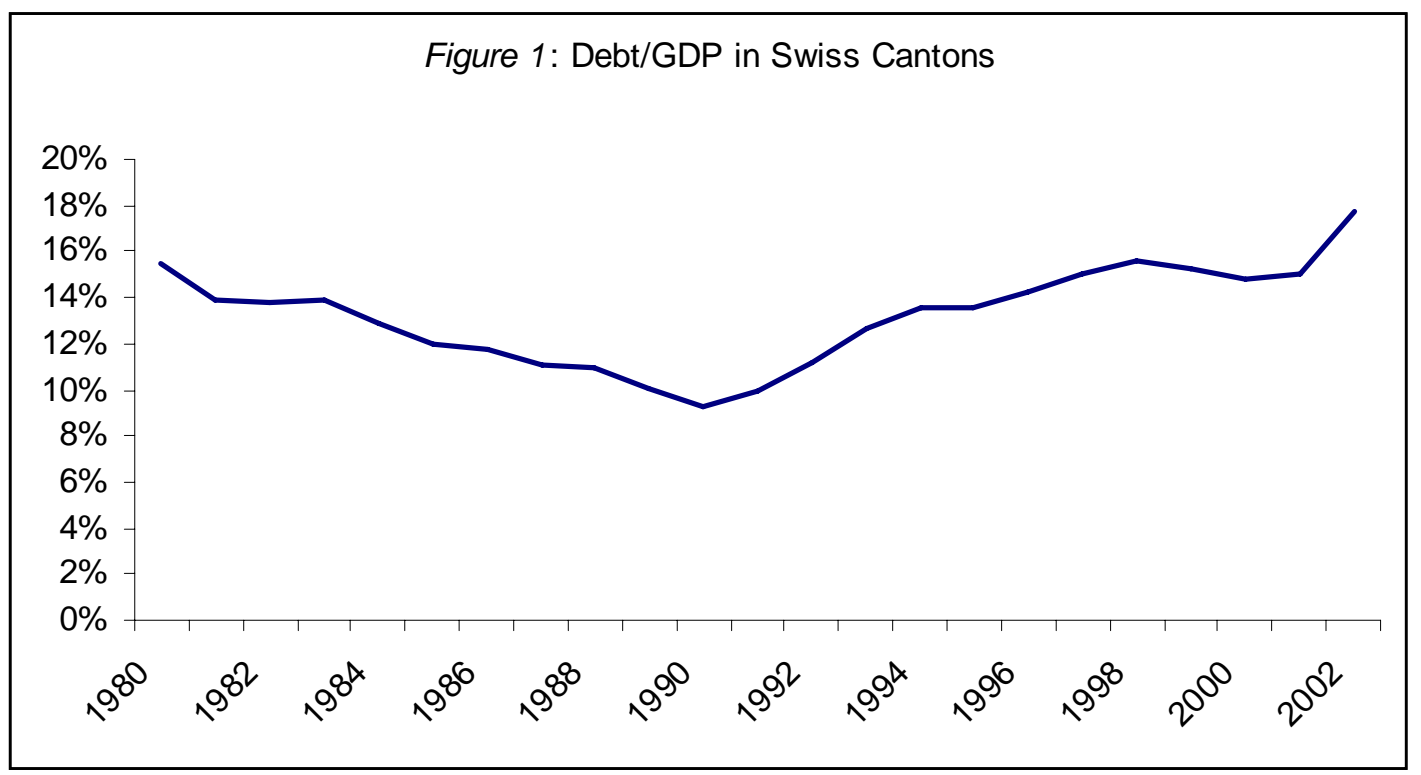

Next, as we focus on episodes of very tight fiscal policy, we consider only relatively large fiscal adjustments according to the following definition: 
Definition 1: A period of fiscal adjustment is defined as a year in which the primary balance per GDP of a canton improves by at least 1 percentage point, or a period of two consecutive years in which the primary balance improves by at least 0.8 percentage points in each year.

Setting this rather demanding threshold, we identify only very tight adjustments that clearly represent a discretionary change in the fiscal stance. According to this definition, for the 1981-2001 period, Switzerland witnessed 62 tight fiscal adjustments. As Table 1 indicates, the deficit reduction is distributed according to a ratio of 1 to 2 between lower spending and higher revenues. It is somewhat surprising that tight fiscal policies are relying more on revenue increases than on spending cuts since it stands in stark contrast to the results for OECD countries (Alesina and Perotti, 1997). However, since the specific design of the distribution formula of intergovernmental grants in Switzerland rewards high tax burdens with a high share of granted transfers, the result is absolutely plausible (Schaltegger and Frey, 2003). It reflects the poor design of the transfer scheme, which eventually is to be changed in 2008 .

Table 1: Fiscal Adjustments in Swiss Cantons: Changes in Primary Spending and Revenues (in percentage points of GDP)

\begin{tabular}{lcccc}
\hline & $\begin{array}{c}\text { Number of } \\
\text { Observations }\end{array}$ & Fiscal Impulse & $\begin{array}{c}\text { Change in Primary } \\
\text { Spending }\end{array}$ & Change in Revenues \\
\hline All Periods & 546 & -0.01 & 0.26 & 0.27 \\
Periods of Fiscal & 62 & $(0.016)$ & $(0.011)$ & $(0.012)$ \\
Adjustment & & -1.60 & -0.47 & 1.14 \\
Difference & & $(0.006)$ & $(0.004)$ & $(0.004)$ \\
& & 1.59 & $0.72^{* * *}$ & $0.87^{* * *}$
\end{tabular}

Note: Standard deviations in parentheses. ${ }^{* * *}, * *$ and $*$ indicate that the difference between the two averages is statistically significant at the level of less than $1 \%$, between 1 and $5 \%$, and between 5 and $10 \%$, respectively.

Having identified the sample of tight fiscal policies, the next step is to assess which of them were successfully. The identification of tight fiscal policy allows us to analyze the success of the fiscal retrenchment according to the following definition: 
Definition 2: A period of fiscal adjustment is considered to have been successful, if in the three years after the adjustment, the primary balance improved on average by at least half a percentage point.

Table 2 summarizes the episodes of successful fiscal adjustments in Switzerland. 17 cases of successful fiscal adjustment could be identified. Most successful consolidations fall on the second part of our period of observation. On average the improvement of the primary balance accounts for 1.60 percentage points as can be seen by Table 1 .

Table 2: Episodes of Successful Fiscal Adjustments in Switzerland

\begin{tabular}{ll}
\hline Canton & Year (Improvement of Primary Balance in Percentage Points of GDP) \\
\hline Uri & $1999(2.06)$ \\
Schwyz & $1982(1.26), 1993(1.20)$ \\
Obwalden & $1998(1.39)$ \\
Nidwalden & $1999(1.42)$ \\
Zug & $1994-1995(1.07), 1995(1.22)$ \\
Solothurn & $1999(2.38)$ \\
Appenzell a.Rh. & $1983(1.76), 1993(1.55)$ \\
Appenzell i.Rh. & $1983(1.53), 1992(1.47)$ \\
Ticino & $1984(1.04), 1998(1.00)$ \\
Neuchâtel & $1993(1.35)$ \\
Genève & $1998(1.06)$ \\
Jura & $1995(2.06)$ \\
\hline
\end{tabular}

In Table 3 we display the magnitude and the composition of the 62 tight fiscal periods divided into successful and unsuccessful consolidations. The difference of the two groups of fiscal adjustments concerns the magnitude and the significance of the change. First, the magnitude of the primary deficit reduction is significantly higher in the unsuccessful cases (-1.66) compared to successful adjustments (-1.45) which somewhat contradicts the "expectation view" in fiscal adjustment. Second, the improvement of the primary balance is based more heavily on revenue increases in unsuccessful (1.19) than in successful (0.98) consolidations. However, the difference is not significant. Despite the fact that the intergovernmental transfer scheme rewards tax in- 
creases, it seems that long-lasting deficit reductions rely slightly less on revenue-based adjustments than unsuccessful adjustments. This result is in line with the "labor-market view" or the “composition view" of fiscal adjustments. Most interestingly, successful consolidations are accompanied by reductions in received federal grants while unsuccessful adjustments have perceived a rise in transfer payments by the federal government.

Table 3: Successful and Unsuccessful Fiscal Adjustments in Swiss Cantons: Changes in Primary Spending and Revenues (in percentage points of GDP)

\begin{tabular}{lccccc}
\hline & $\begin{array}{c}\text { Number of } \\
\text { Observa- } \\
\text { tions }\end{array}$ & $\begin{array}{c}\text { Fiscal } \\
\text { Impulse }\end{array}$ & $\begin{array}{c}\text { Change in } \\
\text { Primary } \\
\text { Spending }\end{array}$ & $\begin{array}{c}\text { Change in } \\
\text { Revenues }\end{array}$ & $\begin{array}{c}\text { Change in Received } \\
\text { Intergovernmental } \\
\text { Transfers }\end{array}$ \\
\hline $\begin{array}{l}\text { Successful Fiscal } \\
\text { Adjustments }\end{array}$ & 17 & -1.45 & -0.47 & 0.98 & -0.07 \\
$\begin{array}{l}\text { Unsuccessful } \\
\text { Fiscal Adjust- }\end{array}$ & 45 & -1.66 & -0.47 & 1.19 & $(0.002)$ \\
ments & & $(0.013)$ & $(0.010)$ & $(0.008)$ & 0.13 \\
Difference & & $0.11^{* *}$ & 0.00 & $0.004)$ & $(0.004)$ \\
\hline
\end{tabular}

Note: Standard deviations in parentheses. ${ }^{* *}, * *$ and $*$ indicate that the difference between the two averages is statistically significant at the level of less than $1 \%$, between 1 and $5 \%$, and between 5 and $10 \%$, respectively.

In Table 4, we show some macroeconomic results for the successful and the unsuccessful adjustments. The results report average values for the two years before the adjustment, during a significant fiscal action and the two years following the last year of the consolidation.

The difference in the macroeconomic effects before, during and in the aftermath between successful and unsuccessful fiscal adjustments is striking. First, successful adjustments occur in periods when the economic situation is much worse than in the unsuccessful cases. However, during successful consolidations the rate of GDP-growth increases by 0.5 percentage points, rising to over 2.4 percentage points including the two-year period after the stabilization. On the contrary, during and two years after the unsuccessful episodes economic growth is increasing much more moderate. Additionally, the data suggest that adjustments are not successful simply because they were implemented in periods of high growth. In fact, during the implementation 
phase of a successful consolidation economic growth was negative. Referring to the literature on "Keynesian versus Non-Keynesian-Effects" of fiscal adjustments, our data favor the latter view on the expansionary effect of fiscal consolidations for the Swiss case. After a successful fiscal consolidation, GDP growth boosts significantly and much more than in the unsuccessful cases.

Table 4: Macroeconomic Effects of Fiscal Stabilizations (in percentage points of GDP)

\begin{tabular}{|c|c|c|c|c|c|c|c|c|c|c|}
\hline & \multicolumn{5}{|c|}{ Successful Adjustments } & \multicolumn{5}{|c|}{ Unsuccessful Adjustments } \\
\hline & $\begin{array}{l}\text { Before } \\
\text { (A) }\end{array}$ & $\begin{array}{l}\text { During } \\
\text { (B) }\end{array}$ & $\begin{array}{l}\text { After } \\
\text { (C) }\end{array}$ & $\begin{array}{c}\text { Diff. } \\
\text { (B-A) }\end{array}$ & $\begin{array}{l}\text { Diff. } \\
\text { (C-A) }\end{array}$ & $\begin{array}{l}\text { Before } \\
\text { (A) }\end{array}$ & $\begin{array}{l}\text { During } \\
\text { (B) }\end{array}$ & $\begin{array}{l}\text { After } \\
\text { (C) }\end{array}$ & $\begin{array}{l}\text { Diff. } \\
\text { (B-A) }\end{array}$ & $\begin{array}{l}\text { Diff. } \\
\text { (C-A) }\end{array}$ \\
\hline $\begin{array}{l}\text { GDP- } \\
\text { Growth }\end{array}$ & $\begin{array}{l}-1.04 \\
(0.023)\end{array}$ & $\begin{array}{l}-0.54 \\
(0.023)\end{array}$ & $\begin{array}{l}1.38 \\
(0.025)\end{array}$ & 0.49 & $2.42 * * *$ & $\begin{array}{l}0.17 \\
(0.026)\end{array}$ & $\begin{array}{l}0.36 \\
(0.028)\end{array}$ & $\begin{array}{l}1.23 \\
(0.023)\end{array}$ & 0.20 & $1.06^{* *}$ \\
\hline$\Delta$ Debt & $\begin{array}{l}0.85 \\
(0.015)\end{array}$ & $\begin{array}{l}1.06 \\
(0.013)\end{array}$ & $\begin{array}{l}-0.29 \\
(0.016)\end{array}$ & 0.21 & $-1.14 * * *$ & $\begin{array}{l}0.51 \\
(0.016)\end{array}$ & $\begin{array}{l}-0.23 \\
(0.014)\end{array}$ & $\begin{array}{l}-0.06 \\
(0.019)\end{array}$ & -0.74 & -0.58 \\
\hline $\begin{array}{l}\Delta \text { Primary } \\
\text { Spending }\end{array}$ & $\begin{array}{l}0.83 \\
(0.013)\end{array}$ & $\begin{array}{l}-0.47 \\
(0.008)\end{array}$ & $\begin{array}{l}-0.03 \\
(0.012)\end{array}$ & $-1.29 * * *$ & $-0.86^{* *}$ & $\begin{array}{l}0.46 \\
(0.012)\end{array}$ & $\begin{array}{l}-0.47 \\
(0.011)\end{array}$ & $\begin{array}{l}0.33 \\
(0.013)\end{array}$ & $-0.92 * * *$ & -0.13 \\
\hline$\Delta$ Revenue & $\begin{array}{l}0.27 \\
(0.010)\end{array}$ & $\begin{array}{l}0.98 \\
(0.015)\end{array}$ & $\begin{array}{l}0.41 \\
(0.010)\end{array}$ & 0.72 & 0.14 & $\begin{array}{l}0.46 \\
(0.010)\end{array}$ & $\begin{array}{l}1.19 \\
(0.009)\end{array}$ & $\begin{array}{l}-0.09 \\
(0.010)\end{array}$ & 0.73 & -0.55 \\
\hline$\Delta$ Transfers & $\begin{array}{l}0.06 \\
(0.003)\end{array}$ & $\begin{array}{l}-0.07 \\
(0.005)\end{array}$ & $\begin{array}{l}0.02 \\
(0.004)\end{array}$ & -0.13 & -0.05 & $\begin{array}{l}0.07 \\
(0.004)\end{array}$ & $\begin{array}{l}0.13 \\
(0.005)\end{array}$ & $\begin{array}{l}0.02 \\
(0.004)\end{array}$ & 0.07 & -0.05 \\
\hline $\begin{array}{l}\Delta \\
\text { Investment }\end{array}$ & $\begin{array}{l}-0.49 \\
(0.025)\end{array}$ & $\begin{array}{l}-0.73 \\
(0.017)\end{array}$ & $\begin{array}{l}0.52 \\
(0.018)\end{array}$ & -0.24 & 1.01 & $\begin{array}{l}-0.05 \\
(0.031)\end{array}$ & $\begin{array}{l}-0.68 \\
(0.026)\end{array}$ & $\begin{array}{l}0.06 \\
(0.053)\end{array}$ & -0.64 & 0.11 \\
\hline $\begin{array}{l}\Delta \text { Un- } \\
\text { employment }\end{array}$ & $\begin{array}{l}42.42 \\
(0.904)\end{array}$ & $\begin{array}{l}-17.69 \\
(0.700)\end{array}$ & $\begin{array}{l}-20.70 \\
(0.589)\end{array}$ & $-60.1^{*}$ & $-63.1 * * *$ & $\begin{array}{l}36.28 \\
(0.969)\end{array}$ & $\begin{array}{l}-25.50 \\
(1.010)\end{array}$ & $\begin{array}{l}-15.03 \\
(0.591)\end{array}$ & $-64.8 * * *$ & $-51.3 * * *$ \\
\hline
\end{tabular}

Note: Standard deviations in parentheses. ${ }^{* *}, * *$ and $*$ indicate that the difference between the two averages is statistically significant at the level of less than $1 \%$, between 1 and $5 \%$, and between 5 and $10 \%$, respectively.

A similar pattern is obviously given by the fiscal stance. When the fiscal situation is bad in terms of rising debt levels, the success of an adjustment policy is more likely than in cases where fiscal conditions are less alarming. Moreover, successful adjustments face a significant reduction of debt levels whereas the debt reduction is more moderate and insignificant in the case of unsuccessful adjustments. When comparing the patterns of primary spending growth, an interesting observation emerges, too. Successful fiscal consolidations are associated with significant and sustainable long-lasting spending cuts while unsuccessful stabilizations perceive a renewed spending boost after a first success in cutting back public expenditures. In the case of public 
revenues, both successful as well as unsuccessful adjustment policies do not increase their revenue capacity during or after the adjustment significantly. Turning to transfers, it is interesting to notice that successful adjustments did not receive significantly additional revenues due to an increase of financial aid by the federal government. Next, successful adjustments experience only slightly and insignificant more investment in their economy after the consolidation. Finally, interesting differences on the labor market can be observed. A successful fiscal adjustment is accompanied by a more sizeable and significant reduction of the rate of unemployment.

Summing up, we can conclude, first, that successful consolidations occur in periods of economic and fiscal stress in terms of negative GDP growth, and rising debt. While this result is in line with the popular notion that governments have to be up against the wall before they act, the argumentation is not entirely free from tautology. Fiscal adjustments become naturally a political issue only when current policies do not seem to work. Second, successful fiscal adjustments show long-lasting and relatively sharper spending cuts than unsuccessful stabilizations. Third, both successful and unsuccessful consolidations experience revenue increases but in the former case, the share of federal aid on these revenues was slightly reduced during the consolidation implementation compared to unsuccessful adjustments with an increasing share of federal aid.

\section{Empirical analysis on the probability of a successful fiscal adjustment}

In this section, our aim is to empirically analyze whether institutional features of a government significantly affect the likelihood of success in consolidation policies. If the two conditions of definition 1 and 2 hold, we assume that a government has undertaken a discretionary cut in the deficit-to-GDP ratio and succeeded in its long-lasting reduction. Thus, we are concerned with large and persistent reductions of government deficits resulting from discretionary budget improvements rather than with small and continuous fiscal changes in the budget. 
We estimate a Probit model to assess the impact of fiscal decentralization on the fiscal consolidation controlling for various independent variables which have been proven to be important explanations of fiscal stabilizations in the literature (see Appendix A for an exact description and Appendix for descriptive statistics of the variables). The dependent variable takes the value 1 if the adjustment is successful and 0 otherwise. As Ardagna (2004) has pointed out, the appropriate sample of country (state)-years that should be included in the empirical estimate can be debate. We follow Ardagna (2004) including all observations in which there is a "need" for fiscal stabilization instead of only considering those years in which we observe a large fiscal contraction. ${ }^{6}$ Since there is no common definition when there is a "need" of fiscal austerity, we cannot distinguish between cases, for which we observe no successful adjustment because there was no need for government action, and those cases, for which stabilization would have been appropriate but the government didn't act. Thus, the disadvantage of our procedure including all observations of the whole sample is that we also consider times when there was no concern of fiscal stabilization. This may result in a downward-bias of the coefficient of successful stabilizations (note 6). The advantage of our procedure is that we do not lose the information from those episodes when fiscal stabilization was not carried out despite of problems of fiscal discipline. Figure 1 supports our empirical procedure as debt-to-GDP levels of Swiss cantons soared after 1990 while state governments reduced debt in the 1980s after the first oil price shock (for longer time-series see Kirchgässner, 2004). Thus, fiscal discipline was recognized as a problem during the first oil crises and became a major political issue in Swiss cantons after 1990.

6 However, we also estimated regressions with a data sample only covering periods of tight fiscal policies (62 periods). The qualitative results (significance of the coefficients) are similar to those reported in Table 5 even though the size of the coefficients is much stronger for the small sample. Results are available upon request. 
Table 5: Likelihood of successful fiscal adjustment. Probit estimates for Swiss cantons

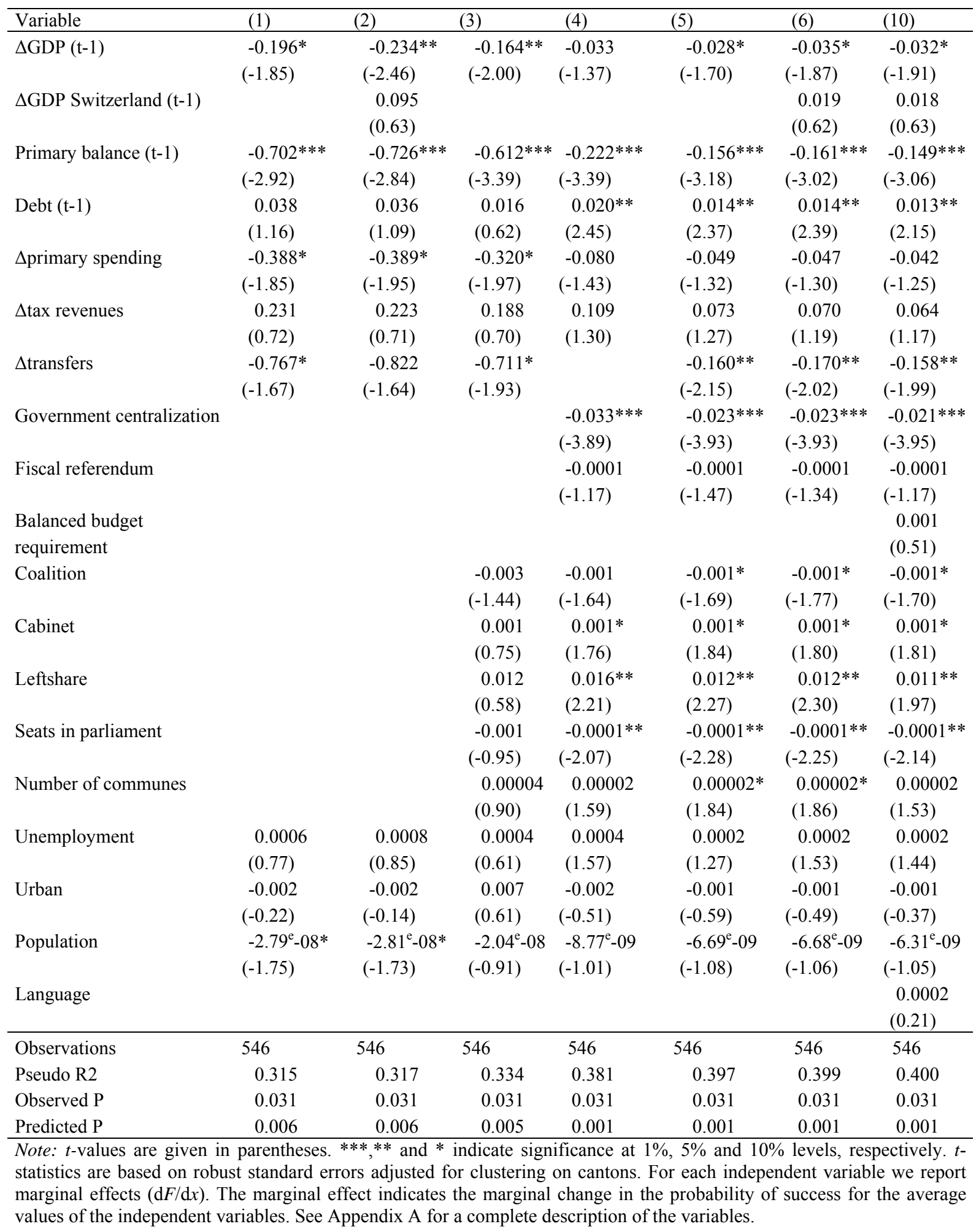

Table 5 displays the results of the empirical investigation for the whole time-series from 19812001 for the Swiss cantons. In the first two columns we follow the basic procedure by Ardagna 
(2004), Tavares (2004) and others to evaluate the impact of different economic and fiscal policy variables on the likelihood of a successful fiscal stabilization including some control variables. First, past economic growth has a negative and statistically significant impact on success. The result implies that problems of fiscal discipline are tackled more seriously in bad times than in years with prosperous economic development. However, business cycle fluctuations common to Switzerland do not seem to have any consequences on fiscal adjustments on the cantonal level. Again and in line with previous results, a high level of primary deficit in the past year strongly increases government's likelihood to stabilize public finances. The same can be concluded by the stock of public debt that increases the chances of success even though the significance of the coefficient is much weaker than for the deficit coefficient. Thus, our results are similar to those obtained by von Hagen and Strauch (2001) for OECD countries arguing that the Maastricht Treaty fostered fiscal discipline in the European governments only to a very small extent at best.

Turning to the composition of the fiscal adjustment, we get some additional interesting results. While an increase in tax revenues to fight fiscal imbalance does not contribute to a successful fiscal consolidation, spending cuts are more promising even though the coefficients turn insignificant after including the institutional variables into the regression. The results correspond to the results obtained by Alesina and Perotti (1997) and Alesina and Ardagna (1998).

The last variable in this group evaluates the effect of federal grants on the successful implementation of fiscal reform. Do federal grants help fiscal adjustments get launched und sustained by alleviating the short-term costs of such a reform? The results in Table 5 do not support such an interpretation. In fact, federal transfers significantly reduce the chance of successful consolidations. A reasonable explanation might be that federal transfers do not only reduce the costs of fiscal adjustments for a cantonal government but also for doing nothing and delaying fiscal stabi- 
lization. As can be seen by column 5, excluding the transfer variable from the regression does not alter the interpretation of the other regressors, so that a possible endogeneity bias does not seem to affect the qualitative interpretation of the results.

Next we turn to the group of politico-institutional variables. First and most interestingly, fiscal decentralization increases the likelihood of successful fiscal adjustment significantly. Decentralized governments are more committed for fiscal austerity packages in times of tight budgets than their centralist counterparts. The size of the coefficient indicates that for the median canton a one-percentage point increase in fiscal centralization reduces the likelihood of a successful adjustment by 0.03 percentage points for all 546 observations. The size of the coefficient rises to 1.7 percentage points if we concentrate on the 62 episodes of tight fiscal policy only. Thus, our results do not support the idea that successful fiscal reforms need an institutional framework for autonomous leadership in which courageous incumbents can pursue austere fiscal policy decisions. Centralist political systems with high policy discretion for incumbents do not support successful fiscal stabilizations. On the contrary, decentralized governments seem to meet fiscal challenges adequately and successfully.

Direct legislation is sometimes seen as another veto-player that may delay stabilization policies. However, our results do not support such an interpretation of the impact of direct democracy. There is no statistically significant negative impact of the fiscal referendum on the success of a fiscal adjustment. Similar results have been obtained by Küttel and Kugler (2003) also for Swiss cantons. This result follows from the logic of the fiscal referendum which allows citizens to veto spending projects above a specific spending threshold (Feld and Matsusaka 2003). It is thus an instrument to prevent spending increases, but does not enable citizens to induce spending reductions and start a fiscal adjustment process. As the fiscal referendum can hamper new spending, it 
does not serve as a general veto instrument like the legislative referendum. If a government proposes spending cuts, citizens cannot use a fiscal referendum to oppose them. It is thus no surprise that the fiscal referendum does not have a significant impact on fiscal consolidation.

Roubini and Sachs (1989), Edin and Ohlsson (1991), Volkerink and de Haan (2000) and others argue that coalition cabinets tend to be fiscally less careful than single majority governments. Alesian and Drazen (1991) theoretically show that too many parties in government delay fiscal stabilizations, and Tavares (2004) and Mierau, Jon-A-Pin and de Haan (2005) empirically examine whether coalition governments have problems of successfully consolidating the budget. Very much in line with Tavares, we find some evidence indicating that coalition cabinets in fact have more difficulties in successfully implementing adjustment policies. However, the effect is very small in our case. Cabinet size does, in contrast to these results, not affect the likelihood of success whereas the size of the parliament matters for fiscal adjustments. Thus, the effect of the type of government on fiscal discipline is different whether we look at public spending and public revenues or public deficits and fiscal adjustments (Schaltegger and Feld, 2004).

Partisan concerns do not matter for success in the Swiss case. This is in contrast to the findings by Ardagna (2004), who provides evidence that left-wing cabinets are more successful in stabilizing the budget, and by Mierau, Jon-A-Pin and de Haan (2005) who find the opposite impact According to Tavares (2004) the partisan impact of the cabinet is differentiated: fiscal adjustment is more successful if right-wing governments raise taxes or if left-wing governments cut spending. Tavares argues that in doing so, governments can signal commitment to the fiscal adjustment since they undertake actions that are not favored by the majority of their constituency.

The other control variables do not exhibit significant coefficients und thus have no impact on the likelihood of successful fiscal adjustments. 


\section{Conclusions}

In this paper we draw attention to the politico-institutional aspect of successful fiscal adjustments. In particular, we study whether fiscal decentralization reduces the ability of a government to consolidate budgets, or increases the credibility and accountability of mutually agreed fiscal consolidations. In theory, both outcomes seem plausible. On the one hand, fiscal decentralization increases the number of veto-players. This creates a status-quo bias when the political system tends to delay stabilization policies. On the other hand, fiscal decentralization strengthens fiscal discipline and fiscal equivalence thereby increasing the credibility of a long-lasting fiscal stabilization. Fiscal decentralization works as a commitment device ensuring that proposed adjustment policies will not be quickly revised after or even during a gubernatorial term.

The evidence favors that the latter interpretation. Fiscal decentralization increases the likelihood of successful budget stabilizations. Thus, centralist government institutions that increase the discretionary leeway of incumbents do not seem to foster long-lasting fiscal adjustments. In addition, the paper presents empirical evidence for the important role of grants-in-aid for subfederal

governments. The estimated results indicate that federal transfer payments reduce the costs of fiscal adjustments thereby delaying the implementation of fiscal reforms.

Another important result is that circumstances matter in which the fiscal adjustment takes place. Adjustments are more likely to be successful, if the deficits in previous years were high and GDP-growth was weak. This is a reasonable result implying that governments become active in bad times when there is need for fiscal reform. Concerning the composition of the fiscal adjustment, spending cuts are more likely to favor long-lasting fiscal adjustments than revenue increases. However, the level of significance is not always within a statistically secure interval. 
Finally, coalition governments and large parliaments have more difficulties in implementing a successful fiscal adjustment than there counterparts.

\section{References}

Alesina, A. and A. Drazen (1991), Why are Stabilizations Delayed?, American Economic Review 81, $1170-1188$.

Alesina, A. and R. Perotti (1995), The Political Economy of Budget Deficits, IMF Staff Papers 42, 1-31.

Alesina, A. and R. Perotti (1997), Fiscal Adjustments in OECD Countries: Composition and Macroeconomic Effects, IMF Staff Papers, 44, 210-248.

Alesina, A. and S. Ardagna (1998), Tales of Fiscal Adjustment, Economic Policy 21, 205-247.

Alesina, A., R. Perotti and J. Tavares (1998), The Political Economy of Fiscal Adjustments, Brookings Papers on Economic Activity 1, 197-248.

Ardagna, S. (2004), Fiscal Stabilizations: When do They Work and Why?, European Economic Review 48, 1047-1074.

Bayoumi, T. and B. Eichengreen (1995), Restraining Yourself: The Implications of Fiscal Rules for Economic Stabilisazion, IMF Staff Papers 42, 32-47.

Bertola, G. and A. Drazen (1993), Trigger Points and Budget Cuts: Explaining the Effects of Fiscal Austerity, American Economic Review 83, 11-26.

Bohn, H. and R.P. Inman (1996), Balanced-Budget Rules and Public Deficits: Evidence from the U.S. States, Carnegie-Rochester Conference Series on Public Policy 45, 13-76.

Buchanan, J.M. and R.E. Wagner (1977), Democracy in Deficit: The Political Legacy of Lord Keynes, Academic Press, New York et al.

Cox, G.W. and M.D. McCubbins (2001), The Institutional Determinants of economic Policy Outcomes, in: Haggard, S. and M.D. McCubbins (eds.), Presidents, Parliaments, and Policy, Cambridge, Cambridge University Press, 21-63.

Crepaz, M.M.L. (1996), Consensus versus Majoritarian Democracy: Political Institutions and Their Impact on Macroeconomic Performance and Industrial Disputes, Comparative Political Studies 29, 426.

Edin, P.-A. and H. Ohlsson (1991), Political Determinants of Budget Deficits: Coalition Effects Versus Minority Effects, European Economic Review 35, 1597-1603.

Feld, L.P. and T.J. Goodspeed (2005), Discretionary Grants and Soft Budget Constraints in Switzerland, mimeo, University of Marburg and Hunter College, New York.

Feld, L.P. and J.G. Matsusaka (2003), Budget Referendums and Government Spending: Evidence from Swiss Cantons, Journal of Public Economics 87, 2703-2724.

Feld, L.P., G. Kirchgässner and C.A. Schaltegger (2003), Decentralized Taxation and the Size of Government, Evidence from Swiss Sub-Federal Governments, mimeo, University of St. Gallen.

Fernandez, R. and D. Rodrik (1991), Resistance to reform: Status Quo Bias in the Presence of IndividualSpecific Uncertainty, American Economic Review 81, 1146-1155.

Giavazzi, F. and M. Pagano (1990), Can Severe Fiscal Contractions Be Expansionary? Tales of Two Small European Countries, NBER Macroeconomic Annual, MIT Press, 75-116. 
Giavazzi, F. and M. Pagano (1996), Non-Keynesian Effects of Fiscal Policy Changes: International evidence and the Swedish Experience, Swedish Economic Policy Review 31, 67-103.

Goodspeed, T.J. (2002), Bailouts in a Federation, International Tax and Public Finance 9, 409-421.

Kirchgässner, G. (2004), Die langfristige Entwicklung der Bundesfinanzen, Jahresbericht 2004 der Kommission für Konjunkturfragen.

Krueger, A.O. (1993), Political Economy of Policy Reform in Developing Countries, MIT Press Cambridge.

Küttel, D. and P. Kugler (2003), Tales of Fiscal Policy, RISEC 50, 91-108.

Mierau, J.O., R. Jon-A-Pin and J. de Haan (2005), Do Political Variables Affect Fiscal Policy Adjustment Decisions? New Empirical Evidence, Paper prepared for presentation at the 2006 European Public Choice Society Meeting at Turku (Finland).

Perotti, R. (1999), Fiscal Policy when Things are Going Badly, Quarterly Journal of Economics 114, 1399-1436.

Pinera, J. (1994), Chile, in: J. Williamson (ed.), The Political Economy of Policy Reform, Washington, Institute for International Economics.

Pitlik, H. (2004), Institutionelle Voraussetzungen marktorientierter Reformen der Wirtschaftspolitik, mimeo, Universität Hohenheim.

Poterba, J.M. (1996), Budget Institutions and Fiscal Policy in the U.S. States, American Economic Review $86,395-400$.

Poterba, J.M. (1997), Do Budget Rules Work?, in: A.J. Auerbach (ed.), Fiscal Policy: Lessons from Economic Research, MIT Press, Cambridge, 53-86.

Rentsch, H. S. Flückiger, T. Held, Y. Heiniger and T. Straubhaar (2004), Ökonomik der Reformen, Zürich, orell füssli.

Rodden, J. (2002), The Dilemma of Fiscal Federalism: Grants and Fiscal Performance Around the World, American Journal of Political Science 46, 670-687.

Rodrik, D. (1996), Understanding Economic Policy Reform, Journal of Economic Literature 34, 9-41.

Roubini, N. and J. Sachs (1989), Political and Economic Determinants of Budget Deficits in the Industrial Economies, European Economic Review 33, 903-938.

Schaltegger, C.A. and L.P. Feld (2004), Do Large Cabinets Favor large Governments? Evidence form Swiss Sub-Federal Jurisdictions, CESifo Working Paper No. 1294.

Schaltegger, C.A. and R.L. Frey (2003), Finanzausgleich und Föderalismus: Zur Neugestaltung der föderalen Finanzbeziehungen am Beispiel der Schweiz, Perspektiven der Wirtschaftspolitik 2, 239-258.

Scharpf, F. (1994), Optionen des Föderalismus in Deutschland und Europa, Frankfurt, Campus.

Scharpf, F. et al. (1976), Politikverflechtung: Theorie und Empirie des kooperativen Föderalismus in der Bundesrepublik, Kronberg, Scriptor.

Shadbegian, R.J. (1999), The Effect of Tax and Expenditure Limitations on the Revenue of Local Government, 1962-87, National Tax Journal 52, 211-217.

Siebert, H. (2005), The German Economy: Beyond the Social Market, Princeton and Oxford: Princeton University Press.

Spolaore, E. (1993), Policy Making Systems and Economic Efficiency, Coalition Governments versus Majority Governments, Ph.D. Dissertation Harvard University. 
Stalder, K. (2005), Fiscal Rules for Cantons and Communes, mimeo University of St. Gallen.

Stauffer, Th.P. (2001), Instrumente des Haushaltsausgleichs: Ökonomische Analyse und rechtliche Umsetzung, Dissertation, University of St. Gallen.

Stiglitz, J. (1998), The Private Uses of Public Interests: Incentives and Institutions, Journal of Economic Perspectives 12, 3-22.

Sutherland, A. (1997), Fiscal Crises and Aggregate Demand: Can High Public Debt reverse the Effects of Fiscal Policy?, Journal of Public Economics 65, 147-162.

Tavares, J. (2004), Does Right or Left Matter? Cabinets, Credibility and Fiscal Adjustments, Journal of Public Economics 88, 2447-2468.

Thiessen, U. (2003), Fiscal Decentralization and Economic Growth in High Income OECD Countries, Fiscal Studies 24, 237-274.

Tommasi, M. and A. Velasco (1996), Where Are We in the Political Economy of Reform?, Policy Reform $1,187-238$.

Trechsel, A. and U. Serdült (1999), Kaleidoskop Volksrechte: Die Institutionen der direkten Demokratie in den schweizerischen Kantonen (1970-1996), Helbing and Lichtenhahn, Basel.

Tsebelis, G. (1995), decision Making in Political Systems: Comparison of Presidentialism, Parliamentarism, Multicameralism, and Multipartism, British Journal of Political Science 25, 289-325.

Tsebelis, G. and E.C.C. Chang (2004), Veto Players and the Structure of Budgets in Advanced Industrialized Countries, European Journal of Political Research 43, 449-476.

Volkerink, B. and J. de Haan (2001), Fragmented Government Effects on Fiscal Policy: New Evidence, Public Choice 109, 221-242.

von Hagen, J. (1991), A Note on the Empirical Effectiveness of Formal Fiscal Restraints, Journal of Public Economics 44, 99-110.

von Hagen J. and R.R. Strauch (2001), Fiscal Consolidations: Quality, Economic Conditions, and Success, Public Choice 109, 327-346.

Wallis, J. (1999), Understanding the Role of Leadership in Economic Policy Reform, World Development 27, 39-53.

Weingast, B.R., K.Shepsle and C. Johnson (1981), The Political Economy of Benefits and Costs: A Neoclassical Approach to Distributive Politics, Journal of Political Economy 96, 132-163.

Williamson, J. (1994, ed.), The Political Economy of Policy Reform. Washington, Institute for International economics.

Zaghini, A. (2001), Fiscal Adjustments and Economic Performing: A Comparative Study, Applied Economics 33, 613-624. 


\section{Appendix A}

\begin{tabular}{|c|c|c|}
\hline \multicolumn{3}{|l|}{ Data description } \\
\hline Variable name & Description & Source \\
\hline$\Delta \mathrm{GDP}(\mathrm{t}-1)$ & $\begin{array}{l}\text { Growth of real cantonal GDP per capita in the } \\
\text { previous year }\end{array}$ & BAK Basel Economics \\
\hline $\begin{array}{l}\Delta \mathrm{GDP} \\
\text { Switzerland (t-1) }\end{array}$ & $\begin{array}{l}\text { Average cantonal growth of real GDP per cap- } \\
\text { ita in the previous year }\end{array}$ & BAK Basel Economics \\
\hline Primary balance $(\mathrm{t}-1)$ & $\begin{array}{l}\text { Nominal primary balance per nominal GDP in } \\
\text { the previous year }\end{array}$ & Swiss Federal Finance Administration \\
\hline Debt $(\mathrm{t}-1)$ & $\begin{array}{l}\text { Nominal cantonal debt per nominal GDP in the } \\
\text { previous year }\end{array}$ & Swiss Federal Finance Administration \\
\hline$\Delta$ primary spending & $\begin{array}{l}\text { Change in nominal primary spending per nomi- } \\
\text { nal GDP }\end{array}$ & Swiss Federal Finance Administration \\
\hline$\Delta$ tax revenues & $\begin{array}{l}\text { Change in nominal tax revenues per nominal } \\
\text { GDP }\end{array}$ & Swiss Federal Finance Administration \\
\hline$\Delta$ transfers & $\begin{array}{l}\text { Change in nominal transfers received from the } \\
\text { federal government per nominal GDP }\end{array}$ & Swiss Federal Finance Administration \\
\hline $\begin{array}{l}\text { Government } \\
\text { Centralization }\end{array}$ & $\begin{array}{l}\text { Share of cantonal public spending from can- } \\
\text { tonal and local spending }\end{array}$ & Swiss Federal Finance Administration \\
\hline Coalition & Number of parties in the cantonal cabinet & anneé politique suisse \\
\hline Cabinet & Number of ministers in the cantonal cabinet & anneé politique suisse \\
\hline Leftshare & $\begin{array}{l}\text { Share of seat by left-wing parties in the can- } \\
\text { tonal parliament }\end{array}$ & anneé politique suisse \\
\hline Seats parliament & Number of seats in the cantonal parliaments & anneé politique suisse \\
\hline $\begin{array}{l}\text { Number of com- } \\
\text { munes }\end{array}$ & Number of communes in a canton & Swiss Federal Statistical Office \\
\hline Unemployment Rate & $\begin{array}{l}\text { Share of unemployment on the cantonal popu- } \\
\text { lation }\end{array}$ & $\begin{array}{l}\text { Own calculations on the basis of Swiss } \\
\text { Federal Statistical Office }\end{array}$ \\
\hline Urban & $\begin{array}{l}\text { Proportion of local communities having more } \\
\text { than } 10^{\prime} 000 \text { inhabitants. }\end{array}$ & Swiss Federal Statistical Office \\
\hline Population & $\begin{array}{l}\text { Cantonal population (logarithmized in the } \\
\text { estimations) }\end{array}$ & Swiss Federal Statistical Office \\
\hline German Language & Share of German Speaking population & Swiss Federal Statistical Office \\
\hline $\begin{array}{l}\text { Balanced budget } \\
\text { requirement }\end{array}$ & $\begin{array}{l}\text { Dummy }=1 \text { for cantons having a formal fiscal } \\
\text { restraint for a given year }\end{array}$ & $\begin{array}{l}\text { Own calculations on the basis of Stauffer } \\
\text { (2001) and Stalder (2005) }\end{array}$ \\
\hline Fiscal referendum & $\begin{array}{l}\text { Dummy }=1 \text { for cantons allowing for manda- } \\
\text { tory budget referendum multiplied with the } \\
\text { inverse of the financial threshold that qualifies } \\
\text { for the ballot }\end{array}$ & $\begin{array}{l}\text { Own calculations on the basis of data from } \\
\text { Trechsel and Serdült (1999) and C2D- } \\
\text { Database }\end{array}$ \\
\hline
\end{tabular}




\section{Appendix B}

\begin{tabular}{|c|c|c|c|c|}
\hline \multicolumn{5}{|l|}{ Descriptive statistics } \\
\hline Variable & Mean & Std. Dev. & Minimum & um \\
\hline Success & 0.031 & 0.174 & 0 & 1 \\
\hline$\Delta \mathrm{GDP}(\mathrm{t}-1)$ & 0.007 & 0.024 & -0.091 & 0.073 \\
\hline$\Delta$ GDP Switzerland (t-1) & 0.009 & 0.016 & -0.016 & 0.036 \\
\hline Primary balance (t-1) & 0.007 & 0.012 & -0.053 & 0.078 \\
\hline $\operatorname{Debt}(\mathrm{t}-1)$ & 0.129 & 0.057 & 0.019 & 0.395 \\
\hline$\Delta$ primary spending & 0.003 & 0.011 & -0.044 & 0.056 \\
\hline$\Delta$ tax revenues & -0.002 & 0.005 & -0.051 & 0.045 \\
\hline$\Delta$ transfers & 0.0002 & 0.003 & -0.014 & 0.013 \\
\hline Centralization & 0.673 & 0.106 & 0.510 & 0.996 \\
\hline Coalition & 3.286 & 0.871 & 1 & 5 \\
\hline Cabinet & 6.381 & 1.208 & 5 & 9 \\
\hline Leftshare & 0.218 & 0.129 & 0 & 0.531 \\
\hline Seats in parliament & 115.0 & 47.5 & 46 & 200 \\
\hline Number of communes & 114.9 & 113.6 & 3 & 412 \\
\hline Unemployment & 0.018 & 0.018 & 0 & 0.078 \\
\hline Urban & 0.324 & 0.249 & 0 & 0.995 \\
\hline Population & 261938 & 272497 & 12781 & 1228628 \\
\hline German Language & 0.714 & 0.353 & 0.050 & 0.980 \\
\hline Balanced budget requirement & 0.106 & 0.308 & 1 & 0 \\
\hline Fiscal referendum (DummyXThreshold ${ }^{-1}$ ) & 1.794 & 4.844 & 0 & 29.328 \\
\hline
\end{tabular}

Notes: For a detailed description of the variables see Appendix A. All statistics are computed for 546 observations. 


\section{CESifo Working Paper Series}

(for full list see www.cesifo-group.de)

1884 Johannes Becker and Clemens Fuest, Corporate Tax Policy and International Mergers and Acquisitions - Is the Tax Exemption System Superior?, January 2007

1885 Momi Dahan and Udi Nisan, The Effect of Benefits Level on Take-up Rates: Evidence from a Natural Experiment, January 2007

1886 José García-Solanes, Francisco I. Sancho-Portero and Fernando Torrejón-Flores, Beyond the Salassa-Samuelson Effect in some New Member States of the European Union, January 2007

1887 Peter Egger, Wolfgang Eggert and Hannes Winner, Saving Taxes Through Foreign Plant Ownership, January 2007

1888 Timothy J. Goodspeed and Andrew Haughwout, On the Optimal Design of Disaster Insurance in a Federation, January 2007

1889 Wim Groot, Henriëtte Maassen van den Brink and Bernard van Praag, The Compensating Income Variation of Social Capital, January 2007

1890 Bas Jacobs, Ruud A. de Mooij and Kees Folmer, Analyzing a Flat Income Tax in the Netherlands, January 2007

1891 Hans Jarle Kind, Guttorm Schjelderup and Frank Stähler, Newspapers and Advertising: The Effects of Ad-Valorem Taxation under Duopoly, January 2007

1892 Erkki Koskela and Rune Stenbacka, Equilibrium Unemployment with Outsourcing under Labour Market Imperfections, January 2007

1893 Maarten Bosker, Steven Brakman, Harry Garretsen, Herman de Jong and Marc Schramm, The Development of Cities in Italy 1300 - 1861, January 2007

1894 Michel Beine, Oscar Bernal, Jean-Yves Gnabo and Christelle Lecourt, Intervention Policy of the BoJ: A Unified Approach, January 2007

1895 Robert S. Chirinko and Daniel J. Wilson, State Investment Tax Incentives: A Zero-Sum Game?, January 2007

1896 Theo S. Eicher and Oliver Roehn, Sources of the German Productivity Demise Tracing the Effects of Industry-Level ICT Investment, January 2007

1897 Helge Berger, Volker Nitsch and Tonny Lybek, Central Bank Boards around the World: Why does Membership Size Differ?, January 2007

1898 Gabriel Felbermayr and Wilhelm Kohler, Does WTO Membership Make a Difference at the Extensive Margin of World Trade?, January 2007 
1899 Benno Torgler and Friedrich Schneider, The Impact of Tax Morale and Institutional Quality on the Shadow Economy, January 2007

1900 Tomer Blumkin and Efraim Sadka, On the Desirability of Taxing Charitable Contributions, January 2007

1901 Frederick van der Ploeg and Reinhilde Veugelers, Higher Education Reform and the Renewed Lisbon Strategy: Role of Member States and the European Commission, January 2007

1902 John Lewis, Hitting and Hoping? Meeting the Exchange Rate and Inflation Criteria during a Period of Nominal Convergence, January 2007

1903 Torben M. Andersen, The Scandinavian Model - Prospects and Challenges, January 2007

1904 Stephane Dees, Sean Holly, M. Hashem Pesaran and L. Vanessa Smith, Long Run Macroeconomic Relations in the Global Economy, January 2007

1905 Richard Jong-A-Pin and Jakob De Haan, Political Regime Change, Economic Reform and Growth Accelerations, January 2007

1906 Sascha O. Becker and Peter H. Egger, Endogenous Product versus Process Innovation and a Firm's Propensity to Export, February 2007

1907 Theo S. Eicher, Chris Papageorgiou and Oliver Roehn, Unraveling the Fortunates of the Fortunate: An Iterative Bayesian Model Averaging (IBMA) Approach, February 2007

1908 Liliana E. Pezzin, Robert A. Pollak and Barbara S. Schone, Efficiency in Family Bargaining: Living Arrangements and Caregiving Decisions of Adult Children and Disabled Elderly Parents, February 2007

1909 Christian Keuschnigg and Soren Bo Nielsen, Self-Selection and Advice in Venture Capital Finance, February 2007

1910 Rune Jansen Hagen and Gaute Torsvik, Irreversible Investments, Dynamic Inconsistency and Policy Convergence, February 2007

1911 Eric A. Hanushek and Ludger Woessmann, The Role of School Improvement in Economic Development, February 2007

1912 Bernard M. S. van Praag, Perspectives from the Happiness Literature and the Role of New Instruments for Policy Analysis, February 2007

1913 Volker Grossmann and Thomas M. Steger, Growth, Development, and Technological Change, February 2007

1914 Margarita Katsimi and Thomas Moutos, Human Capital and the Feldstein-Horioka Puzzle, February 2007 
1915 Oliver Roehn, Theo S. Eicher and Thomas Strobel, The Ifo Industry Growth Accounting Database, February 2007

1916 Ian Babetskii, Aggregate Wage Flexibility in Selected New EU Member States, February 2007

1917 Burkhard Heer, Alfred Maussner and Paul D. McNelis, The Money-Age Distribution: Empirical Facts and Limited Monetary Models, February 2007

1918 Yin-Wong Cheung, Menzie D. Chinn and Eijii Fujii, The Overvaluation of Renminbi Undervaluation, February 2007

1919 Jim Malley, Apostolis Philippopoulos and Ulrich Woitek, To React or Not? Fiscal Policy, Volatility and Welfare in the EU-3, February 2007

1920 Mattias Polborn, Competing for Recognition through Public Good Provision, February 2007

1921 Lars P. Feld and Benno Torgler, Tax Morale after the Reunification of Germany: Results from a Quasi-Natural Experiment, February 2007

1922 Robert S. Chirinko and Huntley Schaller, Fundamentals, Misvaluation, and Investment: The Real Story, February 2007

1923 Benno Torgler and Friedrich Schneider, Shadow Economy, Tax Morale, Governance and Institutional Quality: A Panel Analysis, February 2007

1924 Adrian Pagan and M. Hashem Pesaran, On Econometric Analysis of Structural Systems with Permanent and Transitory Shocks and Exogenous Variables, February 2007

1925 Hans-Werner Sinn, The Welfare State and the Forces of Globalization, February 2007

1926 Michael Smart, Raising Taxes through Equalization, February 2007

1927 Øystein Foros, Kåre P. Hagen and Hans Jarle Kind, Price-Dependent Profit Sharing as an Escape from the Bertrand Paradox, February 2007

1928 Balázs Égert, Kirsten Lommatzsch and Amina Lahrèche-Révil, Real Exchange Rates in Small Open OECD and Transition Economies: Comparing Apples with Oranges?, February 2007

1929 Aleksander Berentsen and Cyril Monnet, Monetary Policy in a Channel System, February 2007

1930 Wolfgang Ochel, The Free Movement of Inactive Citizens in the EU - A Challenge for the European Welfare State?, February 2007

1931 James K. Hammitt and Nicolas Treich, Statistical vs. Identified Lives in Benefit-Cost Analysis, February 2007 
1932 Wilhelm Kohler, The Bazaar Effect, Unbundling of Comparative Advantage, and Migration, February 2007

1933 Karsten Staehr, Fiscal Policies and Business Cycles in an Enlarged Euro Area, February 2007

1934 Michele Bernasconi and Paola Profeta, Redistribution or Education? The Political Economy of the Social Race, March 2007

1935 Axel Dreher, Martin Gassebner and Lars-H. R. Siemers, Does Terror Threaten Human Rights? Evidence from Panel Data, March 2007

1936 Naércio Aquino Menezes Filho and Marc-Andreas Muendler, Labor Reallocation in Response to Trade Reform, March 2007

1937 Gebhard Flaig and Timo Wollmershaeuser, Does the Euro-zone Diverge? A Stress Indicator for Analyzing Trends and Cycles in Real GDP and Inflation, March 2007

1938 Michael Funke and Michael Paetz, Environmental Policy Under Model Uncertainty: A Robust Optimal Control Approach, March 2007

1939 Byeongchan Seong, Sung K. Ahn and Peter A. Zadrozny, Cointegration Analysis with Mixed-Frequency Data, March 2007

1940 Monika Bütler and Michel André Maréchal, Framing Effects in Political Decision Making: Evidence from a Natural Voting Experiment, March 2007

1941 Giacomo Corneo and Olivier Jeanne, A Theory of Tolerance, March 2007

1942 Qing Hong and Michael Smart, In Praise of Tax Havens: International Tax Planning and Foreign Direct Investment, March 2007

1943 Yin-Wong Cheung, Dickson Tam and Matthew S. Yiu, Does the Chinese Interest Rate Follow the US Interest Rate?, March 2007

1944 Panu Poutvaara and Mikael Priks, Unemployment and Gang Crime: Could Prosperity Backfire?, March 2007

1945 Burkhard Heer, On the Modeling of the Income Distribution Business Cycle Dynamics, March 2007

1946 Christoph A. Schaltegger and Lars P. Feld, Are Fiscal Adjustments less Successful in Decentralized Governments?, March 2007 